\title{
The Educational Environment of the University as a Means of Preventing the Ideology of Extremism Among Young People
}

\author{
Elena Bauer ${ }^{1, a *}$, Asil Salavatova1, Rustam Shikhaliyev ${ }^{1}$, \\ 1 Nizhnevartovsk State University, 628605, 56 Lenina str., Nizhnevartovsk, Russia \\ abauerea@yandex.ru \\ *Corresponding author
}

Keywords: extremism, ideology, preventive measures, young people, educational environment

\begin{abstract}
Modern societies are increasingly facing the problem of disregard for the rules of behavior, laws, as well as the emergence of youth associations of a wrongful nature. As a special social and age group in the structure of society and due to the lack of life experience, insufficient legal literacy, lack of values and attitudes, young people are especially influenced by various kinds of negative social tendencies. Often young people have no idea about the ideological basis of extremist phenomena and can often be involved in various extremist groups. The article analyzes the possibilities of countering the ideology of extremism through the educational environment of the university. The authors presented an organizational model for the prevention of the ideology of extremism in the student environment, which allows creating conditions for the formation of a socially responsible, successful person focused on the values of education and citizenship.
\end{abstract}

\section{Introduction}

The stability and further development of any state is directly related to the young generation, which over time will begin to form new economic, national, value, cultural conditions in its country, region, world. In modern conditions, young people can be viewed a special social group in the structure of society, which is characterized by a number of features: a high level of mobility, being in a period of formation of value orientations, experiencing the development of new social roles and professional determinations.

The UN World Program defines education as one of the most important priorities of youth policy, which, in turn, will guarantee professional growth and active work in the future. Therefore, in a special way, the organized educational environment of the university deserves special attention, since this helps to determine the correct life guides of a young person, aims at a socially active position, warns against possible negative influence of society, including such a dangerous sociocultural phenomenon as extremism. It becomes clear that the prevention of socially negative phenomena in the student environment should become one of the leading areas of educational work of the university. The problem is all the more urgent because the value orientations of an individual, formed at a young age, will further express the character of a person's attitude to various aspects of the world and reflect the level of its development, regulate activity and behavior [1].

\section{Materials and research methods}

In world practice, there is a need for a special approach to the formation of ideology among the youth. Often, due to lack of life experience, lack of legal literacy, a tendency towards deviant behavior, young people easily become a fertile ground for radical and extremist ideas. Therefore, it is no coincidence that a number of international documents set the task of providing favorable conditions for living, education, employment, and comprehensive development of young people. These include:

- Declaration on the Promotion Among Youth of the Ideals of Peace, Mutual Respect and Understanding Between Peoples (1965),

- Guidelines for the Long-term Planning and Implementation of Appropriate Coherent Measures for the Youth (1985),

- World Programe of Action for Youth to the Year 2000 and Beyond (1995),

- UN-Habitat Strategy for Increasing Youth Participation (2005), 
- Youth Policy Program "Youth: Investing and Providing Opportunities" for 2010-2018. (2009),

- Resolution on the revised Basics of European Cooperation in the Youth Sphere for 2010-2018 (2009).

In the Russian Federation, official statistics indicate that the number of young people in 2017 was 29.4 million people (or $20 \%$ of the population) [2]. Unfortunately, the dynamics of their numbers is decreasing.

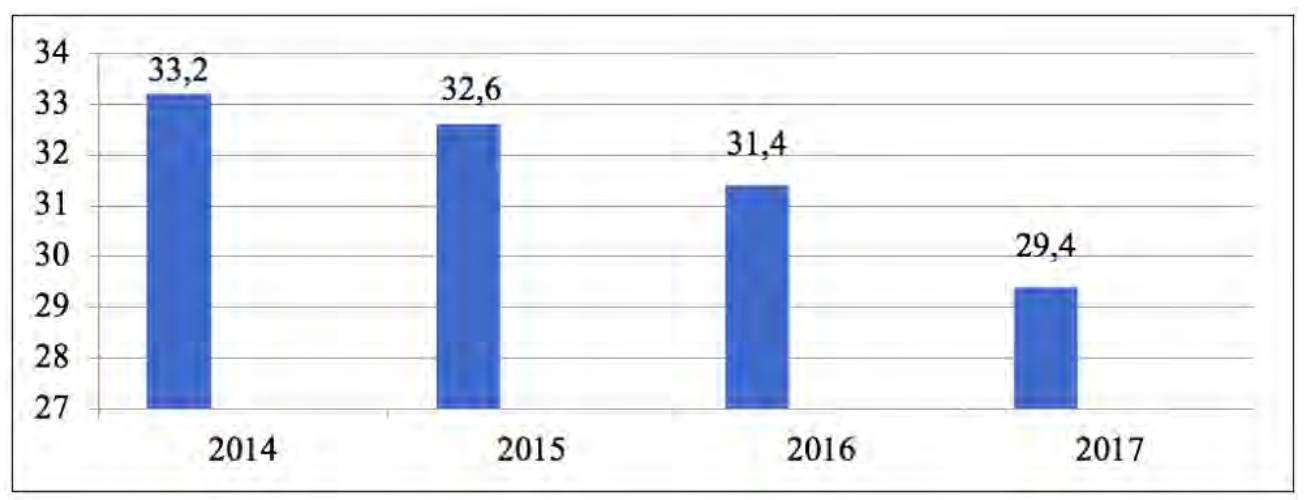

Fig. 1. The number of young people in Russia, 2014-2017.

The following diagram shows that young people between the ages of 18 and 27 (that is, the age at which they receive vocational education and training at a university) make up more than $50 \%$ of all young people.

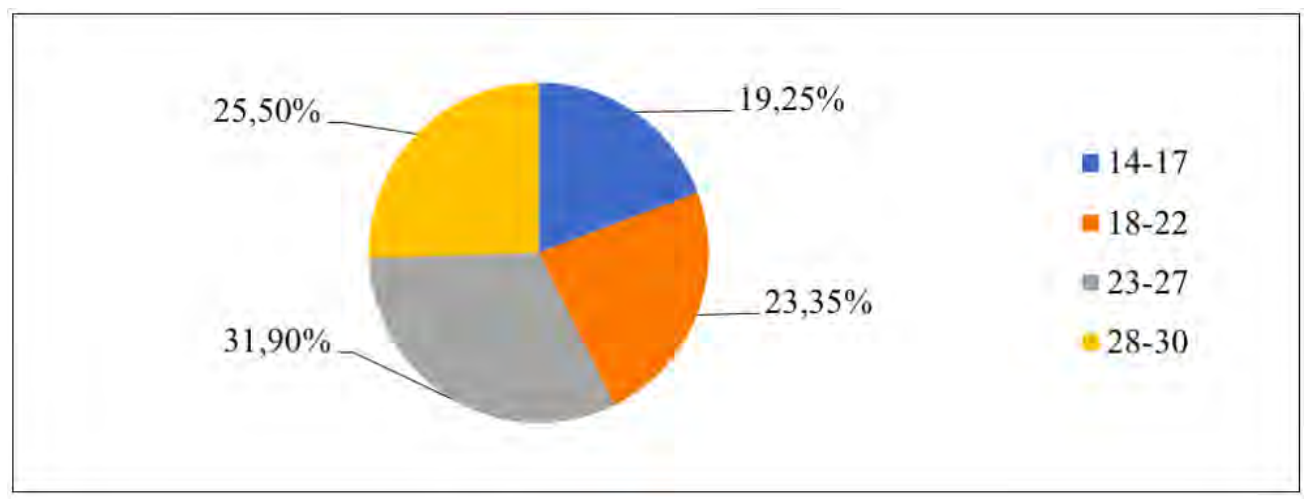

Fig. 2. The age structure of young people in Russia, 2017.

In other words, it is necessary to have a clear understanding of the fact that it is the educational environment of the higher education system that is seriously responsible for solving the problems faced by young people in certain conditions, for expanding their participation in society. The special role of the university is to form a stable negative attitude of young people towards any manifestation of illegal and extremist activity.

\section{Discussion}

In modern conditions, we observe a multidirectional process of studying the problem of preventing the ideology of extremism among young people. On the one hand, in the scientific community and among practitioners, there is a considerable interest in the problem of countering extremism. On the other hand, many experts an ordinary people have an understanding of the importance of preventive work with young people in the educational environment, the content of activities, and their main areas.

Within the framework of the topic, a number of discussion points can be highlighted.

First, in international and Russian practice there is no common understanding of the age limits of young people. According to the UN classification, young people are those whose age is from 14 to 24 years old. At the same time, in Russia the boundaries of young age are defined by the Strategy of the State Youth Policy from 14 to 30 years (in some cases, for example, when it comes to young scientists - even up to 35 years old). Thus, the lack of uniform criteria for age periodization is also reflected in the specifics of the approaches of various disciplines, such as Sociology, Demography, and Pedagogy. 
Secondly, there is a discussion among scholars regarding the content of the concept of "extremism", its types, reasons for the extremist behavior of the youth.

Extremism (in lat., extreme, excessive) is the extreme degree of adherence to certain views of individuals or organizations. The wording of the concept is defined in the federal legislation, but the diversity of manifestations of extremism has given rise to various discussions about its types.

R. R. Gomleshko comes to the conclusion that the sources of extremist activity are, above all, social conditions, such as the deformation of political institutions, falling living standards, unemployment, and insecurity [3].

The attention of I. N. Bochkarev is focused on the following factors of the emergence and spread of extremism among young people: deterioration of the quality of life, low income and well-being, lack of a work and rest system, which negatively affects attitudes towards the government, the state and law enforcement agencies [4]. Since, according to the author, given the current situation in the world community, it is impossible to completely eradicate the ideology of extremism, it is necessary to accumulate close attention on preventing the development of propaganda of the ideology of extremists among young.

We agree with the fair opinion of O.V. Popov, who considers weakening and lack of educational work in educational institutions as the main reasons [5]. Other reasons are seen by the author in the destructive influence of the media, reducing the role and importance of youth public organizations, reducing the political activity of young people.

\section{Results}

In order for the youth environment not to become a fertile ground for the spread of various extremist manifestations (incitement of social, racial, national or religious discord; propaganda of exclusivity or superiority), it is necessary to create an organizational model for the prevention of extremism. Such a model was developed on the basis of the Student Affairs Department of the Nizhnevartovsk State University.

TABLE 1. MODEL OF PREVENTION OF THE IDEOLOGY OF EXTREMISM IN THE STUDENT ENVIRONMENT.

\begin{tabular}{|c|c|c|c|c|}
\hline \multirow[b]{2}{*}{ 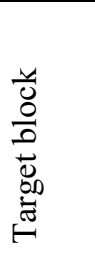 } & \multicolumn{4}{|c|}{$\begin{array}{l}\text { Purpose: to create conditions for the formation of a socially responsible, } \\
\text { successful person, focused on the values of education and citizenship. }\end{array}$} \\
\hline & $\frac{n}{\frac{n}{n}}$ & \multicolumn{3}{|c|}{$\begin{array}{l}\text { - increasing the level of legal, communicative, information culture of } \\
\text { students, } \\
\text { - development of inter-ethnic dialogue and international education, } \\
\text { - activization of student public associations. }\end{array}$} \\
\hline \multirow{6}{*}{ 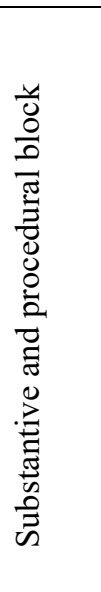 } & \multicolumn{4}{|c|}{$\begin{array}{c}\text { Stages of preventing the ideology of extremism in the educational } \\
\text { environment of the university }\end{array}$} \\
\hline & & Preparatory stage & Main stage & Final stage \\
\hline & \multicolumn{4}{|c|}{$\begin{array}{c}\text { Means of preventing the extremism ideology in the educational environment } \\
\text { of the university }\end{array}$} \\
\hline & \multicolumn{4}{|c|}{$\begin{array}{l}\text { Legal regulations; informational sites, electronic resources, material and } \\
\text { technical means; media; means of educational process }\end{array}$} \\
\hline & \multicolumn{4}{|c|}{$\begin{array}{c}\text { Organizational forms of preventing the extremist ideology in the educational } \\
\text { environment of the university }\end{array}$} \\
\hline & \multicolumn{4}{|c|}{$\begin{array}{l}\text { Group: District Model UN, Discussion Club, excursions to the Museum of } \\
\text { History, Festival of national cultures "Smiles of the world", a student search } \\
\text { group "Pathfinder," curator hours, round tables, etc.). } \\
\text { Indvidual: conversations, consultations. }\end{array}$} \\
\hline \multirow{2}{*}{ 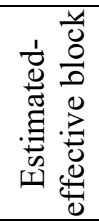 } & \multicolumn{4}{|c|}{$\begin{array}{c}\text { Criteria for preventing the extremist ideology in the educational environment } \\
\text { of the university }\end{array}$} \\
\hline & & $\begin{array}{l}\text { Number of } \\
\text { events } \\
\text { held }\end{array}$ & $\begin{array}{c}\text { Proportion of } \\
\text { students } \\
\text { participating in events }\end{array}$ & $\begin{array}{l}\text { Number of } \\
\text { trained } \\
\text { specialists }\end{array}$ \\
\hline
\end{tabular}




\begin{tabular}{|c|c|c|c|}
\hline & $\begin{array}{c}\text { Number of } \\
\text { active } \\
\text { public } \\
\text { associations }\end{array}$ & $\begin{array}{c}\text { Proportion of students who } \\
\text { positively } \\
\text { evaluate the results of } \\
\text { events held }\end{array}$ & $\begin{array}{c}\text { Dynamics of } \\
\text { illegal activities } \\
\text { motivated by } \\
\text { extremism }\end{array}$ \\
\cline { 2 - 4 } & \multicolumn{3}{|c|}{ Levels of prevention } \\
\cline { 2 - 4 } & \multicolumn{2}{|c|}{ Average } & Low \\
\hline Hesult & $\begin{array}{l}\text { Organization and functioning of a model for the } \\
\text { prevention of extremist ideology among students }\end{array}$ \\
\hline
\end{tabular}

\section{Conclusion}

Currently, the problem of the spread of extremist ideology in society is relevant because it is dangerous for society and is a problem for the whole world. The most dangerous, in terms of entering the field of extremist activity, is the age of 14 to 25 years. Due to insufficient social maturity and lack of experience, young people may be affected to a greater extent; therefore, the educational system is faced with timely tasks to increase the level of students' legal, communicative, information culture; development of inter-ethnic dialogue and international education; activization of student public associations.

Preventing youth extremism is the most effective way to combat the spread of negative ideology, since educational measures can give the best results.

\section{References}

[1] Ibragimova, L.A., Istrofilova, O. I. (2014). Realization of the value approach in education: a collective monograph.. Nizhnevartovsk, Russia: Publishing House of Nizhnevartovsk State University.

[2] Rosmolodezh. (n.d.). The Federal Agency for Youth Affairs. Retrieved from https://fadm.gov.ru/activity/statistic.

[3] Gomleshko, R. R. (2011). Youth extremism in the modern sociocultural space. Bulletin of the Adyghe State University. Series 1: Regional Studies: Philosophy, History, Sociology, Jurisprudence, Political Science, Cultural Studies, 2, pp. 184-190.

[4] Bochkarev, I. N., \& Yakovleva, T. E. (2016). Counteraction to the ideology of extremism among young people. In Opposition to the ideology of extremism in the educational environment. Materials of the scientific-practical conference. Moscow, Russia.

[5] Popov, O. V., \& Popova, O. O. (2008). Causes and features of extremism in the youth environment. Measures to counter youth extremism. Scientific statements of BelSU. Series: Philosophy. Sociology. Low, 3. Retrieved from http://cyberleninka.ru/article/n/prichiny-i-osobennosti-ekstremizma-vmolodyozhnoy-srede-mery-protivodeystviya-molodyozhnomu-ekstremizmu. 